\title{
Immune profiling of the bone marrow microenvironment in patients with high-risk localized prostate cancer
}

\author{
Erika Heninger ${ }^{1}$, Nan Sethakorn ${ }^{2}$, David Kosoff ${ }^{3}$, Peiman Hematti ${ }^{1,3}$, Morgan D. \\ Kuczler ${ }^{5}$, Kenneth J. Pienta ${ }^{4,5,6}$ and Joshua M. Lang ${ }^{1,3}$ \\ ${ }^{1}$ University of Wisconsin Carbone Cancer Center, Madison, WI, USA \\ ${ }^{2}$ Department of Oncology, University of Wisconsin, Madison, WI, USA \\ ${ }^{3}$ Department of Medicine, University of Wisconsin, Madison, WI, USA \\ ${ }^{4}$ Department of Oncology, Sidney Kimmel Comprehensive Cancer Center, The Johns Hopkins School of Medicine, Baltimore, \\ MD, USA \\ ${ }^{5}$ Department of Urology, The James Buchanan Brady Urological Institute, Baltimore, MD, USA \\ ${ }^{6}$ Department of Pharmacology and Molecular Sciences, The Johns Hopkins School of Medicine, Baltimore, MD, USA \\ Correspondence to: Joshua M. Lang, email: jmlang@medicine.wisc.edu \\ Keywords: prostate cancer; bone marrow; tumor microenvironment; immune profiling; immune landscape \\ Received: July 28, $2020 \quad$ Accepted: October 29, $2020 \quad$ Published: November 17, 2020
}

Copyright: ( 2020 Heninger et al. This is an open access article distributed under the terms of the Creative Commons Attribution License (CC BY 3.0), which permits unrestricted use, distribution, and reproduction in any medium, provided the original author and source are credited.

\section{ABSTRACT}

Bone marrow (BM) is a primary metastatic site in prostate cancer (PC) and bone invasion is considered incurable. $T$ cell-mediated immune surveillance is essential in controlling both tumorigenesis and initiation of metastases. Beside tropism, dissemination of PC cells to the BM may be facilitated by defects in BM immune homeostasis predisposing this niche to colonization.

To evaluate the BM immune microenvironment in locally advanced, nonmetastatic PC, we performed flow cytometry analysis of myeloid and lymphoid subsets in BM aspirates and peripheral blood collected during prostatectomy. Healthy BM aspirates served to establish a reference range for comparison.

We found alterations in BM immune composition of PC patients, including an increased CD4/CD8 ratio, enrichment of $\mathrm{CD}^{+} \mathrm{T}$ cells, increased $\mathrm{CD} 56^{+}{ }^{+} \mathrm{CD} 3^{+} \mathrm{NKT}$ and CD56+CD3- NK yields compared to healthy controls. The lymphoid phenotype remained comparable regarding $\mathrm{T}$ cell activation and chemokine receptor-based polarization patterns. Additionally, we found increased B7H3 expression in the myeloid monocyte/ macrophage subset and decreased DC infiltration in BM of PC patients.

These findings suggest that alterations in the immune milieu may limit immune surveillance that compromise the ability of the BM microenvironment to prevent tumor dissemination, and predispose development of bone metastases in a subset of patients with localized PC.

\section{INTRODUCTION}

The immune system provides critical protection against tumor progression and dissemination and can induce dramatic, even complete tumor regression in advanced stages of disease. Augmenting antitumor immune responses has become a successful cancer treatment strategy that has driven significant improvements in progression-free and overall survival for patients with a wide range of malignancies [1-5].
Unfortunately, immune targeting therapies have had limited success in the treatment of prostate cancer (PC) so far and the varied pathways by which prostate tumor cells are able to subvert immune responses continue to be under active investigation [6-11].

PC immune subversion within the bone marrow (BM) is an area of particular interest, which may have important implications for PC progression and high clinical relevance for patients. The BM is a crucial hematopoietic organ and a source of anti-tumor immune 
cells. Tumor reactive $\mathrm{T}$ cells in the BM have been shown to induce dramatic tumor regressions in an array of cancers and these $\mathrm{T}$ cells have even been found to be more potent than tumor reactive $T$ cells in the peripheral circulation [12-14]. Yet, despite these potent anti-tumor properties, PC cells are able to disseminate to the BM with great frequency. The BM is the most common site of PC metastases and progression of these metastatic foci are a primary cause of morbidity and death for patients [15]. The establishment and progression of PC metastases within this potentially hostile environment suggests that $\mathrm{PC}$ induces alterations in BM immune homeostasis, which permits survival of metastatic foci. However, such alterations in the BM immune landscape, particularly in men with early state, localized disease, have not yet been clearly defined.

In this study, we aimed to identify alterations within the BM immune microenvironment that could promote the establishment and progression of BM metastases in men with clinically localized PC. We developed multiparameter flow cytometry assays to define the pre-metastatic immune profile in blood and BM samples from patients with localized, high-risk PC undergoing radical prostatectomy. In addition to activation and basic differentiation features of the lymphoid and myeloid compartments, we assessed a variety of chemokine-receptor profiles and expression of positive and negative co-stimulatory markers to gain more granularity of polarization status of both lymphoid and myeloid cells beyond composition. To our knowledge, this study provides the most comprehensive analysis of the BM immune microenvironment in patients with localized PC.

\section{RESULTS}

In order to evaluate for alterations in the BM immune microenvironment of men with primary, localized PC, we developed two highly polychromatic flow cytometry assays to analyze and characterize the lymphoid and myeloid immune infiltrate within the BM. We included markers for several main lymphoid and myeloid immune subsets as well as markers for polarization and activation (markers summarized in Supplementary Table 1). We then employed these assays to analyze the $\mathrm{BM}$ aspirates of men with localized PC as well as healthy controls. Our analysis included $27 \mathrm{BM}$ aspirates that were collected at the time of radical prostatectomy from patients with primary, localized PC and 10 healthy BM donor aspirates. Additionally, in a partial cohort of 14 PC patients and 6 healthy donors the immune analysis was expanded to evaluate cell activation and polarization patterns of $\mathrm{BM}$ infiltrating immune subsets. For the men in the PC cohort, we also obtained matched peripheral blood (PB) samples to analyze along with their BM aspirates. Assay and instrument standardization protocols were established using Mid-Range Ultra-Comp Rainbow beads. Analysis was performed using the FlowJo software. Debris, dead cells and aggregates were excluded from analysis to reduce autofluorescence. After we established our protocol and gating strategies, we analyzed the lymphoid and myeloid composition of PC BM aspirates and compared these findings to the panel of healthy donors.

\section{Lymphoid immune subsets}

We first evaluated the basic lymphoid composition of BM aspirates (Figure 1). The gating strategy is represented in Figure 1A. Compared with healthy donors, we observed that the frequency of $\mathrm{CD} 45^{+}$cells was significantly higher in the PC BM aspirates $(31.56 \%$ vs $58.81 \%, p=0.0016$ ) and that within this CD45 population, there was an enrichment of total $\mathrm{CD} 45^{+}$lymphocytes $\left(\mathrm{CD} 45^{\text {bright }} / \mathrm{SSC}_{\text {low }}\right)(12.65 \%$ vs $22.04 \%$, HBM vs PC, respectively, $p=0.0368)$. On analysis of the lymphocyte subset, we found an increase of $\mathrm{CD}^{+} \mathrm{T}$ cells $\left(\mathrm{CD}^{+} /\right.$ $\left.\mathrm{CD} 5^{\text {bright }} / \mathrm{SSC}_{\text {low }}\right)(8.503 \%$ vs $14.09 \%, p=0.0469)$ while frequency of $\mathrm{CD} 19^{+} \mathrm{B}$ cells $\left(\mathrm{CD} 19^{+} / \mathrm{CD} 45^{\text {bright }} / \mathrm{SSC}_{\text {low }}\right)$ remained comparable between the two groups. The yield of $\mathrm{NK}$ cells (CD56 ${ }^{+} / \mathrm{CD} 3-/ \mathrm{CD} 45^{\text {bright }} / \mathrm{SSC}_{\text {low }}$ ) was significantly higher in PC marrow $(0.8727 \%$ vs $3.852 \%$, $p=0.0224)$ and there was a 10 -fold enrichment of BM infiltrating NKT cells $\left(\mathrm{CD}^{2} 6^{+} / \mathrm{CD}^{+} / \mathrm{CD} 45^{\text {bright }} / \mathrm{SSC}_{\text {low }}\right)$ in PC BM compared to healthy donors $(0.1502 \%$ vs $1.558 \%$, $p=0.0077)$. The increase in NKT frequencies was also significantly higher in PC BM vs HBM when normalized to the $\mathrm{CD}_{4} 5^{+}$infiltrate $(0.4957 \%$ in $\mathrm{HBM}$ vs $3.109 \%$ in PCBM, $p=0.0052$, data not shown).

To assess the lymphoid compartment with more granularity, we evaluated the ratio of $\mathrm{CD}^{+} \mathrm{T}$ cells and $\mathrm{CD}^{+} \mathrm{T}$ cells (Figure 2). We observed a significant increase of the CD4/CD8 ratio in total live cells in PC $\mathrm{BM}$ samples compared to healthy aspirates (mean of 0.97 vs 1.54 , HBM vs PCBM, respectively, $p=0.0363$ ). The CD4 to CD8 ratio was similarly higher in PC BM when normalized to the CD45 infiltrate (mean of 0.97 vs 1.51 , HBM vs PCBM, respectively, $p=0.0441$ ) or to the $\mathrm{CD}^{\text {bright }} / \mathrm{SSC}_{\text {low }}$ lymphocyte subset (mean of 0.97 vs 1.53 , HBM vs PCBM, respectively, $p=0.0387$ ) (Supplementary Figure $1 \mathrm{~A}$ and $1 \mathrm{~B}$, respectively). We have analyzed the CD4/CD8 ratio of a total of $24 \mathrm{~PB}$ samples from the enrolling PC patients (22 out of 24 were matched to BM aspirates), which resulted an average of 2.04, matching the expected healthy reference [16-18]. To identify the factor behind the skewed CD4 to CD8 ratio in BM, we looked at the frequency of both $\mathrm{CD} 4^{+} \mathrm{T}$ cells and $\mathrm{CD} 8^{+} \mathrm{T}$ cells in the aspirates. We detected a significant increase in both CD4 and CD8 frequencies of the total live cell content when compared the PC cohort to healthy donor samples (4.3\% vs $1.3 \%, p=0.0007$ and $3.6 \%$ vs $1.4 \%, p=0.0037$, PC vs HBM, respectively), however, the fold increase was higher in the CD4 subset than in CD8 (3.4 vs 2.6-fold, respectively) suggesting a robust $\mathrm{CD} 4$ infiltration in $\mathrm{PC}$ patients accounting for the skewed CD4 to CD8 ratio. 
Next, we looked at the phenotypic characteristics of infiltrating $\mathrm{CD}^{+}$(Figure 3 ) and $\mathrm{CD}^{+} \mathrm{T}$ cells (Figure 4). We analyzed $\mathrm{T}$ cell activation and found that expression levels of $\mathrm{CD} 28$ in both the $\mathrm{CD}^{+}$and $\mathrm{CD}^{+}$subsets were comparable with the healthy cohort (Figures 3A and 4A, respectively). We then analyzed the expression of various chemokine receptors (CXCR3, CCR4, CXCR5, CCR6) on both CD4 (Figure 3) and CD8 T cells (Figure 4) that are characteristically expressed by distinct functional subsets including Th1/Tc1, Th2/Tc2, Tfh/Tfc, Th17/Tc17, respectively [19]. CXCR3 is considered an inflammatory chemokine receptor, that is rapidly induced on activated
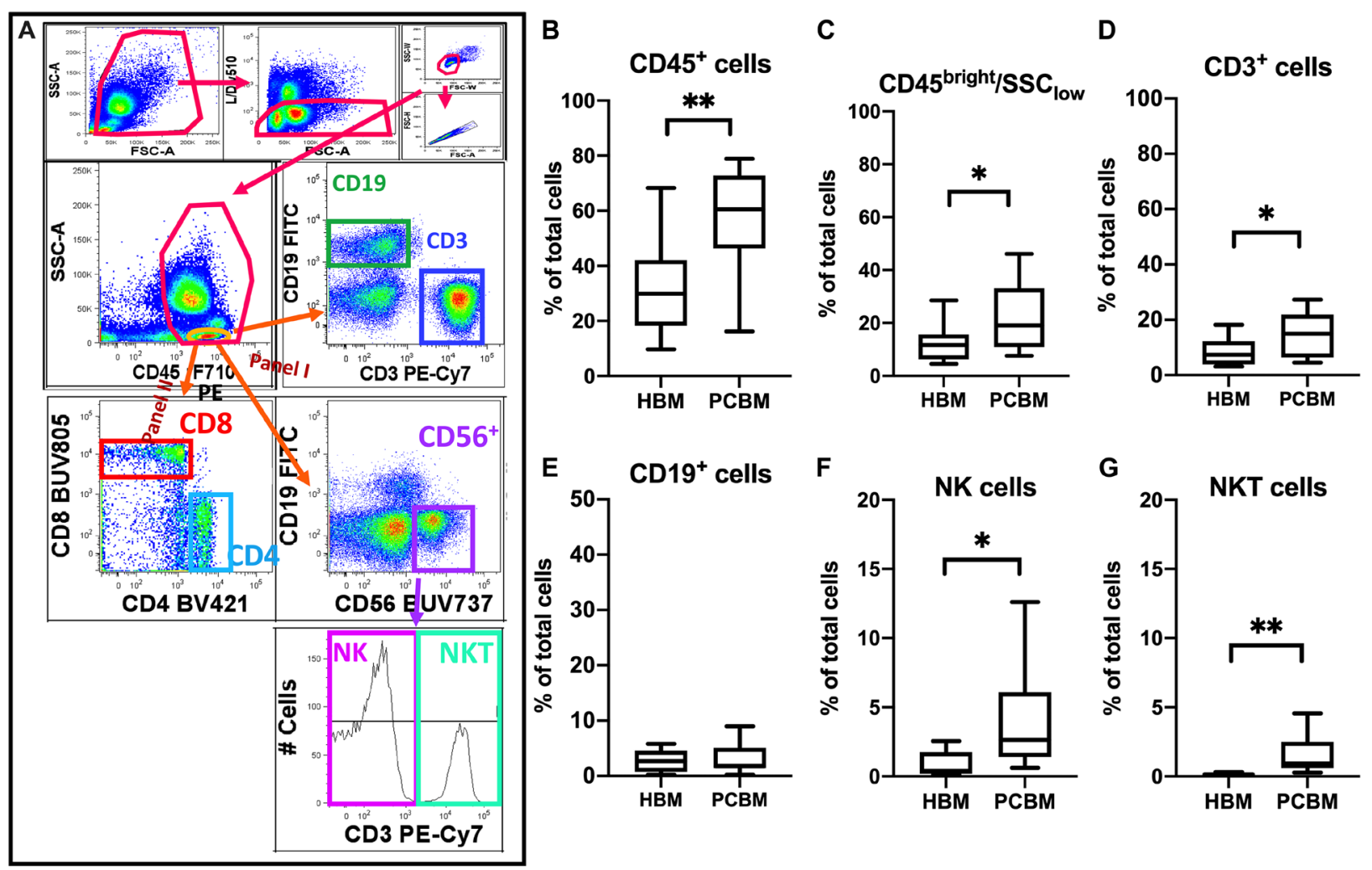

Figure 1: Flow cytometry analysis of lymphoid cellular subsets in BM aspirates. Flow cytometry analysis in (A) represents the gating strategy utilized to analyze lymphoid immune subsets. The top row shows basic quality control gating to reduce autofluorescence by excluding debris, dead cells and aggregates using FSC, SSC Area (A), Height (H) and Width (W) and live/dead staining. Total CD45 cells were then gated and lymphoid cells were conventionally defined as the CD45 $5^{\text {bright }} / \mathrm{SSC}_{\text {low }}$ subset (circled in orange in second row, left dot plot) followed by extraction of the $\mathrm{CD}^{+}$and $\mathrm{CD} 19^{+}$events in Panel I. NK and NKT cells were sub-gated within the CD56 lymphoid subset as $\mathrm{CD}^{-}$and $\mathrm{CD}^{+}$, respectively. Box plots represent the frequency of $(\mathbf{B})$ total $\mathrm{CD}^{-} 5^{+}$events $(\mathbf{C}) \mathrm{CD} 5^{\text {bright }} / \mathrm{SSC}_{\text {low }}$ lymphoid cells

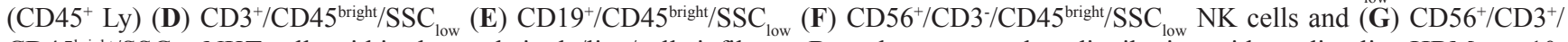
$\mathrm{CD} 45^{\text {bright }} / \mathrm{SSC}_{\text {low }}$ NKT cells within the total single/live/cells infiltrate. Box plots present data distribution with median line HBM $n=10$, $\operatorname{PCBM} n=14$ (B-E); $\operatorname{HBM} n=6, \operatorname{PCBM} n=11(\mathrm{~F}-\mathrm{G}) .{ }^{*} p<0.05 ;{ }^{* *} p<0.01$.
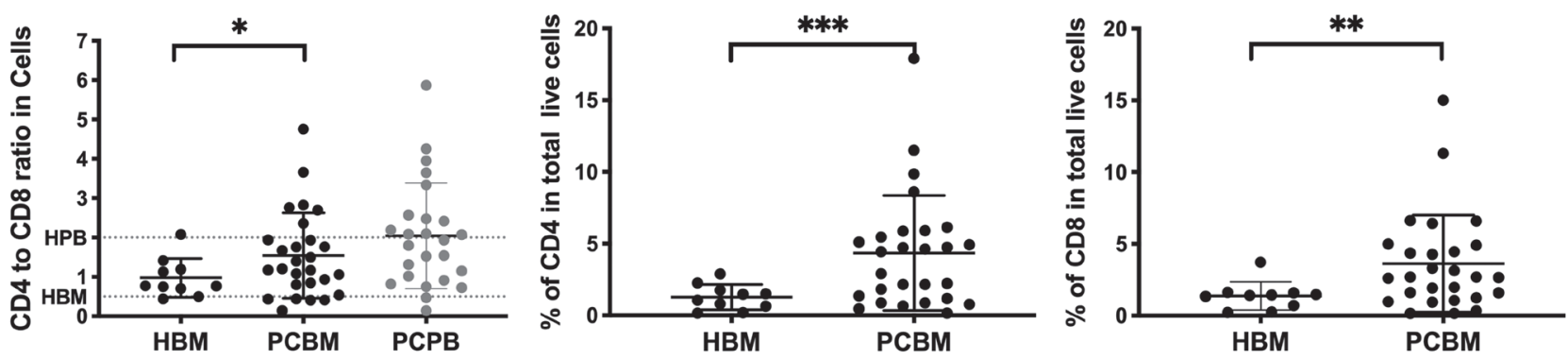

Figure 2: Flow cytometry analysis of the CD4 to CD8 ratio. Dot plot on left shows the CD4 to CD8 ratio in healthy BM aspirates (HBM in black) PC patient BM aspirates (PCBM in black) and PC patient peripheral blood (PCPB in grey). Dotted lines represent previously reported expected reference values for healthy peripheral blood (HPB) and healthy bone marrow (HBM). The dot plots in the middle and right represent frequencies of $\mathrm{CD}^{+}$or $\mathrm{CD}^{+}$cells in total live cell infiltrate. Data is presented as individual data points with Mean $\pm \operatorname{SD} . \operatorname{HBM} n=10, \operatorname{PCBM} n=27, \operatorname{PCPB} n=24 .{ }^{*} p<0.05 ;{ }^{* *} p<0.01$. 
$\mathrm{T}$ cells and remains preferentially and highly expressed on Th1-type CD4 cells and on cytolytic CD8 T cells [20]. We have measured the frequency of both total CXCR3 ${ }^{+}$ cells (Figures 3B and 4B) and the CXCR3 $3^{\text {bright }}$ subset (Figures 3C and 4C) within the CD4 and CD8 cells. Gating strategies for the $\mathrm{T}$ cell analysis are shown in Supplementary (Supplementary Figure 2A).

Chemokine expression patterns for CXCR3, CXCR3 $3^{\text {bright }}$, CCR4, CXCR5, CCR6, (Figures 3 and $4 \mathrm{~B}-4 \mathrm{~F}$ respectively) were comparable between the PC patient group and healthy aspirates. Similarly, we found no differences in the frequency of $\mathrm{CD} 103^{+} / \mathrm{CD}^{+}$(Figure $3 \mathrm{G})$ cells between the two groups.

We assessed the intracellular expression of the FoxP3 regulatory $\mathrm{T}$ cell marker in both the $\mathrm{CD}^{+}$and $\mathrm{CD}^{+} \mathrm{T}$ cell subsets (Figures $3 \mathrm{H}$ and $4 \mathrm{G}$, respectively) and found no evidence of regulatory $\mathrm{T}$ cell enrichment in the bone marrow aspirates of $\mathrm{PC}$ patients. We also calculated the $\mathrm{CD} 8$ to $\mathrm{T}_{\text {reg }}\left(\mathrm{CD}^{+}\right.$to $\left.\mathrm{CD}^{+} \mathrm{FoxP}^{+}\right)$and $\mathrm{Th} 17$ to $\mathrm{T}_{\text {reg }}$ ratios $\left(\mathrm{CD}^{+} \mathrm{CCR}^{+}\right.$to $\left.\mathrm{CD}^{+} \mathrm{FoxP}^{+}\right)$and observed no differences (data not shown).

\section{Myeloid immune subsets}

To identify and define distinct myeloid subsets, we employed both specific surface markers and conventional indirect methods [21] using side scatter (SSC) and Boolean gating strategies depicted in Figure 5A. First, we gated $\mathrm{CD}^{2} 5^{+}$cells that co-expressed the CD11b pan-marker, then gated on the $\mathrm{CD} 14_{\text {low }}$ events that also scattered high on SSC to separate granulocytes (GR) $\left(\mathrm{CD} 11 \mathrm{~b}^{+} / \mathrm{CD} 14_{\text {low }} /\right.$ $\mathrm{SSC}_{\text {high }}$ ) [21]. Next, we gated on the $\mathrm{CD} 11 \mathrm{~b}^{+}$cells and excluded the GR-like events $\left(\mathrm{CD}_{11 \mathrm{~b}}+\mathrm{CD} 14_{\text {low }} / \mathrm{SSC}_{\text {high }}\right)$ (gating strategy shown in Figure 5A) [21] to further enrich for other myeloid subsets including monocytes, macrophages, dendritic cells, myeloid-derived suppressor cells (MDSCs). To enrich the monocyte/macrophage (MO/MF) fraction, we gated on $\mathrm{CD} 14^{+}$events. Within the CD14 gate, we defined $\mathrm{CD}^{-} 1 \mathrm{~b}^{+}$dendritic cells (DC) as the $\mathrm{HLA} \mathrm{II}^{+}$fraction and MDSCs as the HLA II- events.

We established the frequency of the myeloid subsets within the total $\mathrm{CD}^{+} 5^{+}$infiltrate including granulocytes $\left(\mathrm{GR}=\mathrm{CD} 11 \mathrm{~b}^{+} / \mathrm{CD} 14_{\text {low }} / \mathrm{SSC}_{\text {high; }}\right.$ non-GR = Boolean inverted GR gate), monocytes/macrophages $(\mathrm{MO} / \mathrm{MF}=$ nonGR/CD $\left.11 b^{+} / \mathrm{CD} 14_{\text {high }}\right), \mathrm{CD} 11 \mathrm{~b}^{+}$dendritic cells $(\mathrm{DC}=$ nonGR/CD11b $/ \mathrm{CD} 14_{\text {low }} \mathrm{HLA} \mathrm{II}^{+}$) and MDSCs (nonGR/ $\mathrm{CD} 11 \mathrm{~b}^{+} / \mathrm{CD} 14_{\text {low }} \mathrm{HLA} \mathrm{II}^{-}$) (Figure 5B-5E, respectively). While granulocyte, monocyte/macrophage and MDSC yields were all comparable between the PC and healthy cohort, we detected a significant decrease in the frequency

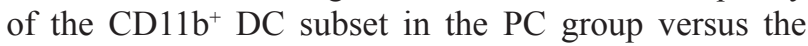
healthy cohort $(1.622 \%$ vs $0.8671 \%, p=0.0347)$.

Next, we assessed polarization patterns within the myeloid immune microenvironment and compared that between a cohort of 11 PC patients and 6 healthy donors. We first analyzed the phenotype of the CD11 ${ }^{+}$
DC subset and found comparable expression levels of CD40 (Figure 5F). Next, we analyzed the expression of two negative checkpoint molecules from the B7-H family on DCs, B7H3 and PDL1 (aka B7H1). While we observed some increase of $\mathrm{B} 7 \mathrm{H} 3$ expression in the $\mathrm{PC}$ cohort, that remained only a tendency (Figure 5G). PDL1 expression was comparable between the two cohorts (Figure $5 \mathrm{H}$ ). The expression of HLA II (DR, DP, DQ) was also similar between the groups (Figure 5I). To further assess the profile of the $\mathrm{MO} / \mathrm{MF}$ subset in BM aspirates (Figure 6), we analyzed the expression levels of several activation and polarization markers including CD14 $4^{\text {bright }}$, HLA II, CD163 ${ }^{\text {bright }}$, CD200R (Figure 6A-6D, respectively) and found them all comparable between the two cohorts. In addition, we measured expression of co-stimulatory molecules including positive co-stimulatory CD40 (Figure 6E), and negative check-point molecules B7H3 and PDL1 (Figure $6 \mathrm{~F}$ and $6 \mathrm{G}$, respectively). We have found a robust increase in the frequency of $\mathrm{B} 7 \mathrm{H} 3^{+} \mathrm{MO} /$ MF cells between the healthy donor vs PC patient aspirates (7.2\% vs $32.3 \%, p=0.0052)$ while the expression of both PDL1 and CD40 were comparable on MO/MF cells between the groups. Next, we aimed to analyze macrophage polarization patterns in the BM aspirates. Alternative macrophage polarization has been associated with tumor-promoting microenvironments. CD163 is a hemoglobin scavenger receptor and is a macrophageexclusive protein [22]. CD200R is an immune-inhibitory protein that is expressed more broadly by myeloid cells and T cells $[23,24]$. The upregulation of both of these proteins have been associated with alternative M2-like macrophage activation. We established a gating strategy to enrich for M2-like and M1M0-like subsets within the $\mathrm{MO} / \mathrm{MF}$ population (Figure 5A). To enrich the M2-like $\mathrm{MO} / \mathrm{MF}$ cells, we pooled events that were either HLAII $\mathrm{OR} \mathrm{HLAII}^{+} / \mathrm{CD} 163^{\text {bright}} / \mathrm{CD} 200 \mathrm{R}^{-} \mathrm{OR} \mathrm{HLAII}^{+} / \mathrm{CD}^{200 \mathrm{R}^{+} /}$ $\mathrm{CD} 163^{\text {low }} \mathrm{OR} \mathrm{HLAII}^{+} / \mathrm{CD} 200 \mathrm{R}^{+} / \mathrm{CD} 163^{\text {bright }}$ in a Boolean gate. The exclusion $\mathrm{HLAII}^{+} / \mathrm{CD} 163^{\text {low }} / \mathrm{CD} 200 \mathrm{R}^{-} \mathrm{MO} / \mathrm{MF}$ subset enriched M1-like and M0 unpolarized cells, defined as 'M1M0-like' in our gating strategy. In Figure $6 \mathrm{H}$ and $6 \mathrm{I}$, we show the frequencies of the enriched M1M0-like or M2-like MO/MF subsets, respectively. The ratio of these two subpopulations has been calculated and shown in Figure 6J. We did not find evidence of an M1/M2 polarization shift in BM in the PC group.

\section{Clinical features and immunologic correlations}

Finally, we obtained clinical outcome data for our patient cohort, summarized in Table 1. Median age of patients was 65 year (49-76). 3.23\% of the cases (1 out of 29 patients) were T3bN1, 35.48\% (11 out of 29) were T3aN0 and $54.83 \%$ of the cases (17 out of 29 patients) were T2N0 stage. None of the patients had radiographic metastasis at the time of prostatectomy and the range of Gleason score was between 6 and 9 . 
Next, we have conducted multiple correlation analysis between immunologic features and clinical data. Spearman r' correlations between clinical data and a subset of basic immune features of both $\mathrm{BM}$ and $\mathrm{PB}$ in the PC cohort are shown in the top matrix of Figure 7. Expectedly, we detected correlations between the Gleason score and TNM stage (represented as T stage in correlation matrix) (Spearman's rho $=0.37$, confidence interval $(\mathrm{CI})$ 0.008468 to $0.6544, p=0.049$ ) and Gleason score and PSA (Spearman rho $=0.38$, CI 0.002054 to $0.6604, p=$ 0.043 ). When analyzing immunologic features, we found a correlation between PSA levels and the frequency of $\mathrm{CD}^{+}$ $T$ cell infiltrates of the total live cellular content of the BM aspirate (Spearman's rho $=0.42$, CI 0.04551 to 0.0.7192, $p=0.027)$. PSA levels at the time of prostatectomy also showed a strong positive correlation with NKT cell enrichment in our patient cohort. This correlation was more enhanced in BM (Spearman's rho $=0.661$, CI 0.08026 to $0.9065, p=0.031$ ) compared to $\mathrm{PB}$ (Spearman's rho $=0.351$, CI 0.3338 to $0.7931, p=0.288$ ). Interestingly, NKT yields projected as the frequency of total leukocyte content $\left(\mathrm{CD}^{4} 5^{+}\right.$total) also correlated with Gleason score (Spearman's rho $=0.643$, CI 0.0517 to $0.9009, p=0.037$ ), TNM stage (Spearman's rho $=0.693$, CI 0.1390 to 0.9165 , $p=0.030$ ) beyond PSA levels (Spearman's rho $=0.615, \mathrm{CI}$ 0.003543 to $0.8918, p=0.049$ ) (Supplementary Figure 3).

The bottom heat map in Figure 7 represents a correlation matrix of a second set of immune features selected from the
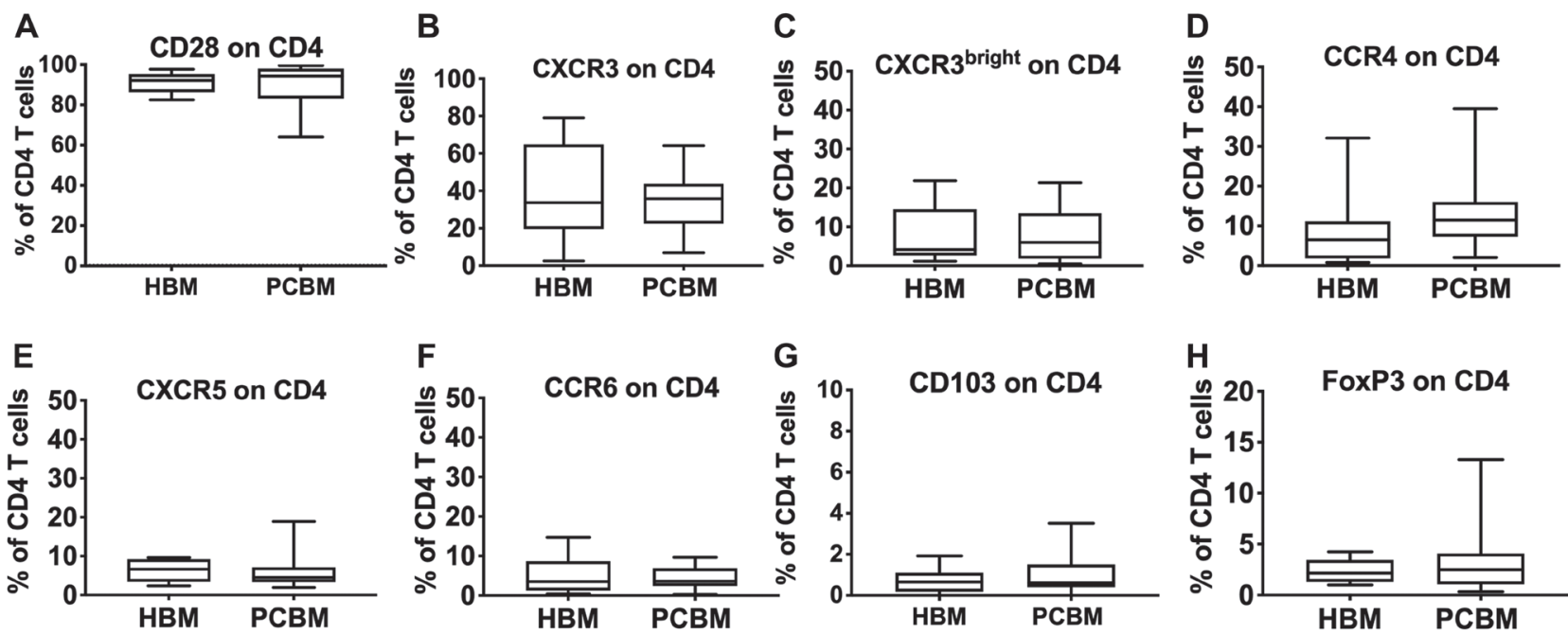

Figure 3: Flow cytometry analysis of CD4 infiltrates. Graphs represent frequency of CD28 (A), CXCR3 (B), CXCR3 ${ }^{\text {bright }}(\mathbf{C})$, CCR4 (D), CXCR5 (E), CCR6 (F), CD103 (G) or FoxP3 (H) positive events within the CD4 $4^{+}$gate. HBM $n=10$, PCBM $n=14(\mathrm{~A}-\mathrm{G})$, $\operatorname{PCBM} n=27(\mathrm{H})$. Box plots represent data distribution with median line, Min to Max.
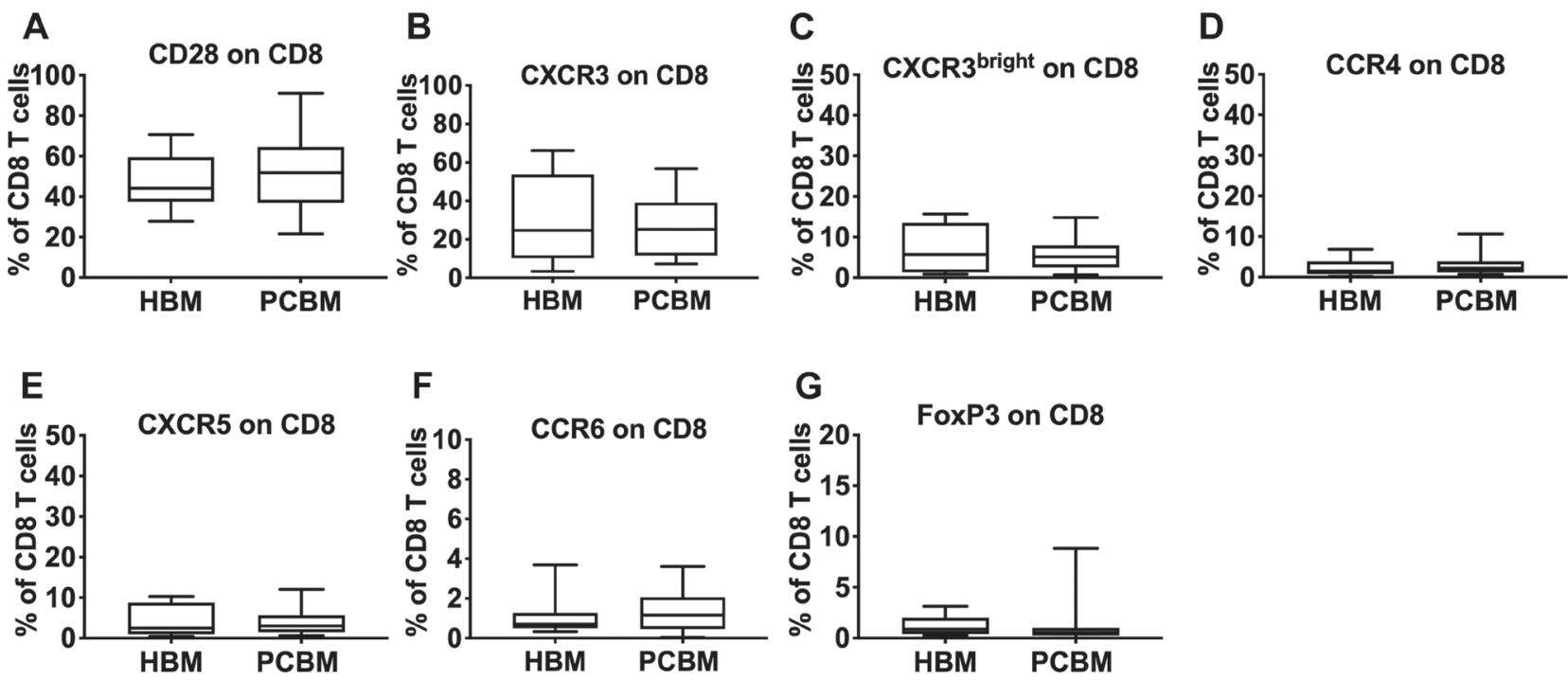

Figure 4: Flow cytometry analysis of CD8 infiltrates. Graphs represent frequency of CD28 (A), CXCR3 (B), CXCR3 ${ }^{\text {bright }}(\mathbf{C})$, CCR4 (D), CXCR5 (E), CCR6 (F) or FoxP3 (G) positive events within the CD8 ${ }^{+}$gate. HBM $n=10, \mathrm{PCBM} n=14$ for $(\mathrm{A}-\mathrm{F}), \mathrm{PCBM} n=$ $27(\mathrm{G})$. Box plots with whiskers represent data distribution with median line, Min to Max. 
high granularity assay in BM aspirates. The expression of B7H3 negative costimulatory marker on both DCs (Spearman rho $=0.631$, CI 0.03029 to $0.8971, p$ value $=0.041)$ and $\mathrm{MO} /$ MF (Spearman rho $=0.627$, CI 0.02267 to $0.8956, p=0.043$ ) subsets also correlated with age. Interestingly, a negative correlation was detected between the yield of GR-like cells within the total $\mathrm{CD} 45^{+}$leukocyte content and Gleason scores (Spearman rho $=-0.558, \mathrm{CI}-0.8452$ to $-0.02209, p$ $=0.040$ ). A heat map of additional data from the multiple correlation analysis is shown in the Supplementary Material (Supplementary Figure 3).

\section{DISCUSSION}

While the ability of PCs to subvert anti-tumor immunity in the BM has been well documented $[25,26]$, the immune landscape of bone invasion and the specific pathways that enable tumor cell survival within this immune-rich environment is still poorly understood partly due to the lack of in-depth reference data. In this study, we sought to assess the pre-metastatic immune profile and potential mechanisms of immune evasion permitting development of metastatic foci. Using independently developed companion flow cytometry assays of 21 distinct immune markers, we identified an array of immune alterations within the BM of patients with clinically localized PC. These alterations, which occurred in the absence of detectable bone metastases, may represent key events in the development of bone invasion and suggest that the process of immune subversion in the BM begins prior to the arrival of disseminating tumor cells.

CD4 and CD8 T cells homeostasis is a critical factor, in both primary tumor and at metastatic sites orchestrating anti-tumor activity [27-29]. In our evaluation of the BM lymphoid populations, we identified a significant increase in the $\mathrm{CD} 4 / \mathrm{CD} 8$ ratio in PC patients relative to healthy controls while the CD4/CD8 ratio in peripheral blood remained within the healthy reference range [16-18]. Although variations in the immune phenotype have been reported in both blood and $\mathrm{BM}$ due to immune senescence,
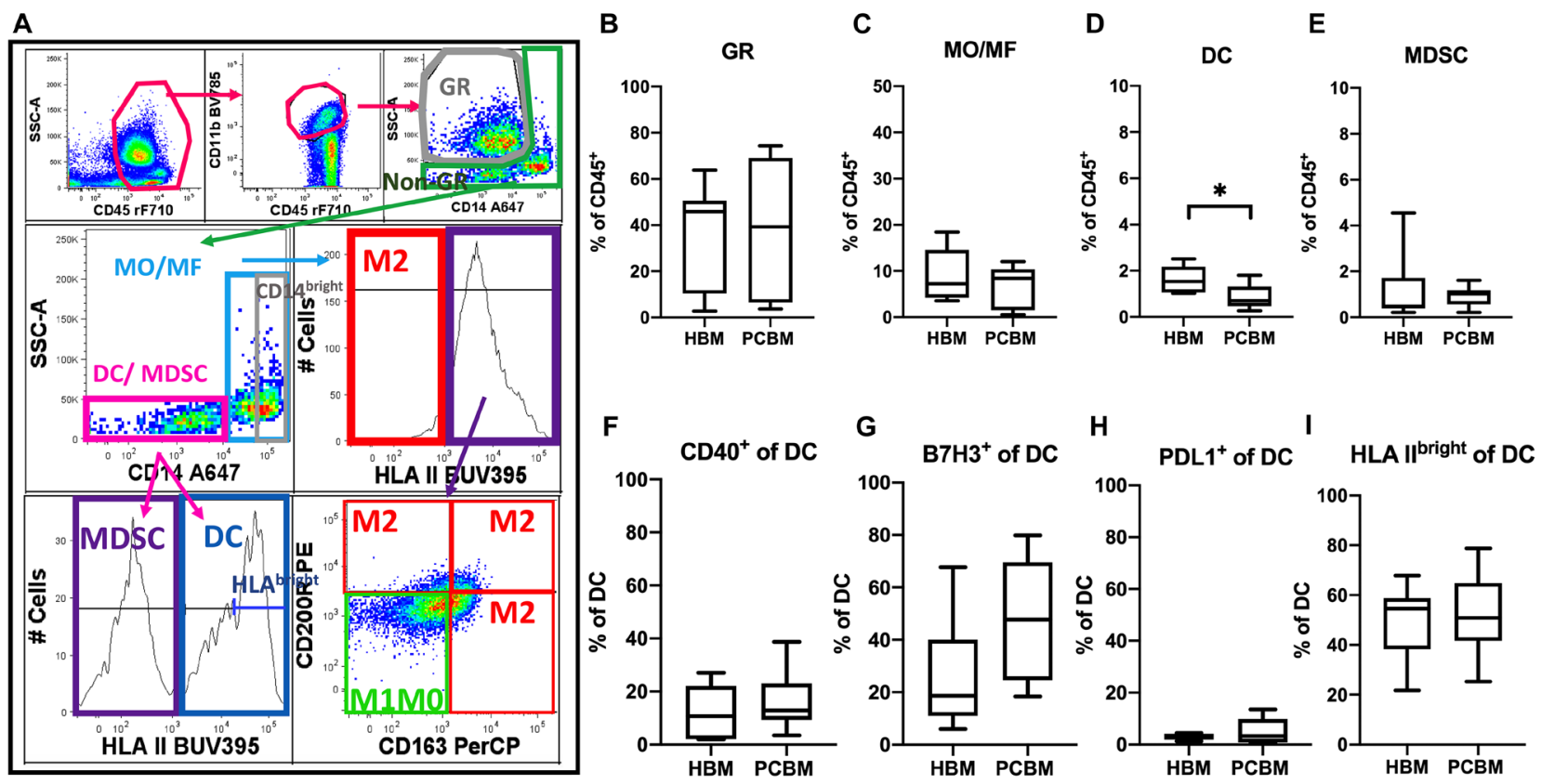

Figure 5: Flow cytometry analysis of myeloid cellular subsets in BM aspirates. (A) Represents the myeloid gating strategy. The $\mathrm{CD} 45^{+}$subset was extracted after exclusion of debris, dead cells and aggregates, followed by gating on the CD11b pan-marker for myeloid cells. Within the $\mathrm{CD} 11 \mathrm{~b}^{+}$subset, we have outlined granulocytes (GR) as pictured on the dot plot on top far right $\left(\mathrm{CD} 14_{\text {low }} / \mathrm{SSC}_{\text {high }}\right)$. Then, we excluded GR cells with a Boolean invert gating strategy (non-GR) and projected these events on the CD14 expression spectrum (middle row, left). The CD14 cells (including DC and MDSC) were then sub-gated for HLA II expression (bottom row, left). HLA II ${ }^{+}$events were defined as a subset that enriched in CD11 $\mathrm{b}^{+}$dendritic cells (DC). The HLA II- events contain myeloid-derived stem cells (MDSC) beside other progenitors not characterized further in this study. Monocytes and macrophages (MO/MF) were then gated as the $\mathrm{CD} 14^{+} /$non-GR component (middle row, left). M1M0 and M2-like MO/MF were enriched by a Boolean gating strategy as follows. M1M0-like cells were defined as $\mathrm{HLAII}^{+}$AND NOT expressing CD200R OR CD163 ${ }^{\text {bright }}$ (lower left quadrant in dot plot in bottom row, left; M1M0-like = green

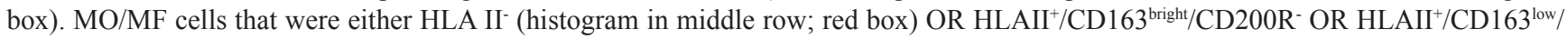
$\mathrm{CD}^{200 \mathrm{R}^{+}} \mathrm{OR} \mathrm{HLAII}^{+} / \mathrm{CD}_{163}$ bright/CD200R ${ }^{+}$(bottom row right) were rendered in a Boolean gate that pooled and enriched M2-like cells. Box plots in the first row represent frequencies of enriched $(\mathbf{B})$ granulocytes $\left(\mathrm{CD} 11 \mathrm{~b}^{+} / \mathrm{CD} 14_{\text {low }} / \mathrm{SSC}_{\text {high }}\right), \mathrm{HBM} n=10, \mathrm{PCBM} n=14 ;(\mathbf{C})$

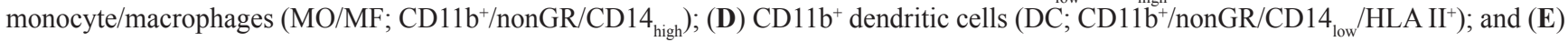

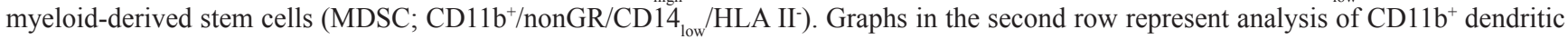
cells in $\mathrm{BM}$ aspirates. Data represent percent of $\mathrm{CD} 40^{+}, \mathrm{B} \mathrm{H}^{+}$, $\mathrm{PDL}^{+}$and HLA II ${ }^{\text {bright }}$ events within the DC subset (F-I, respectively). Box plots with whiskers represent data distribution with median line, $\min$ to $\max$.; $\mathrm{HBM} n=6$, $\mathrm{PCBM} n=11(\mathrm{C}-\mathrm{I}) .{ }^{*} p<0.05$. 


\begin{tabular}{|c|c|c|c|}
\hline Median Age & \multicolumn{3}{|c|}{$65(49-76)$} \\
\hline Median PSA & \multicolumn{3}{|c|}{$5.3(3-27.5)$} \\
\hline & & $n$ & $\%$ \\
\hline \multirow[t]{3}{*}{ pTMN Stage } & T3N1 & 1 & 3.22 \\
\hline & T3N0 & 11 & 35.48 \\
\hline & T2N0 & 17 & 54.83 \\
\hline \multirow[t]{6}{*}{ Gleason Score } & $5+4=9$ & 1 & 3.23 \\
\hline & $4+5=9$ & 4 & 12.90 \\
\hline & $4+4=8$ & 1 & 3.23 \\
\hline & $4+3=7$ & 4 & 12.90 \\
\hline & $3+4=7$ & 16 & 51.61 \\
\hline & $3+3=6$ & 3 & 9.68 \\
\hline
\end{tabular}

peripheral $\mathrm{CD} 4 / \mathrm{CD} 8$ ratios remain largely unchanged over age [16]. In the BM in particular, but in blood and lymph nodes an increase in the CD4/CD8 ratio has been associated with greater risk of BM involvement as well as worse clinical patient outcomes in follicular lymphoma [30]. A decrease of CD4 to CD8 ratio in prostate tissue was reported in a cohort of PC patients following cryo-ablation of tumor nodes reflecting a restoration of $\mathrm{T}$ cell homeostasis in response to therapy [31]. Therefore, an increase of BM CD4/CD8 T cell ratio may reflect an important deviation in $\mathrm{T}$ cell homeostasis during primary $\mathrm{PC}$ pathogenesis, which may ultimately permit bone invasion in these patients. Our current analysis, however, has not identified a specific CD4 or CD8 T cell subpopulation to account for this change. Future studies should explore a potential deviation in $\mathrm{T}$ cell differentiation and assess $\mathrm{T}$ cell exhaustion and senescence that might also contribute to shifts in CD4-CD8 T cell homeostasis in the pre-metastatic BM niche.

Beside the enrichment of conventional T cell subsets, we also observed an increase of unconventional lymphoid cells including NK and NKT cells in PC BM aspirates. A retrospective study found correlation between peripheral NK cell functionality and time to castration resistance and overall survival in metastatic PC [32]. A high dimensional
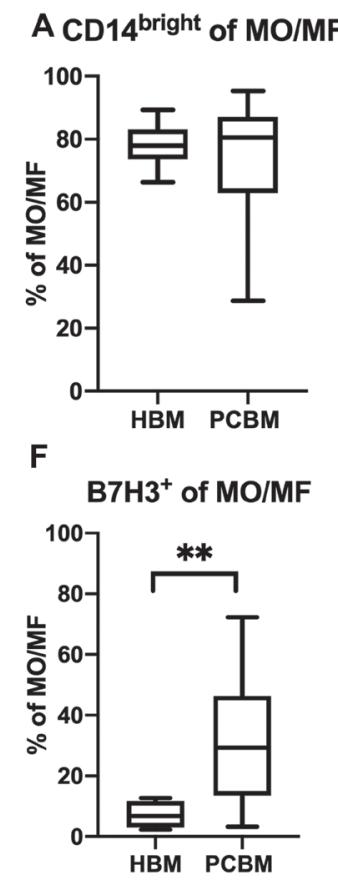

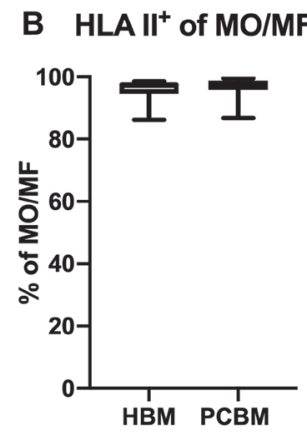

G

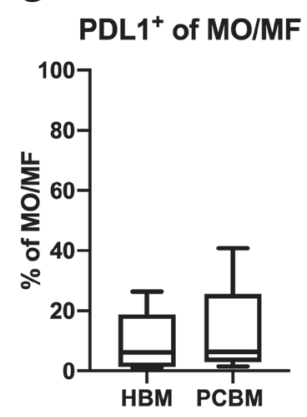

C CD163 bright of MO/MF

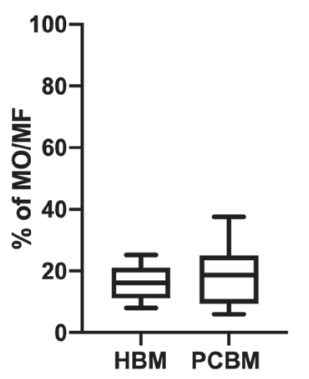

H

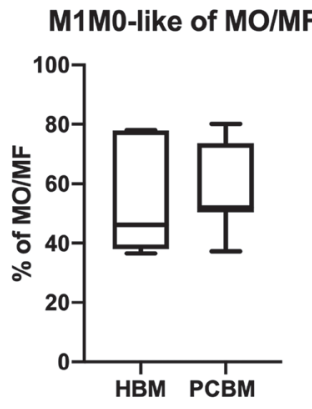

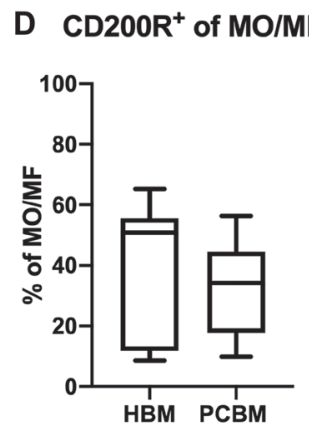

I

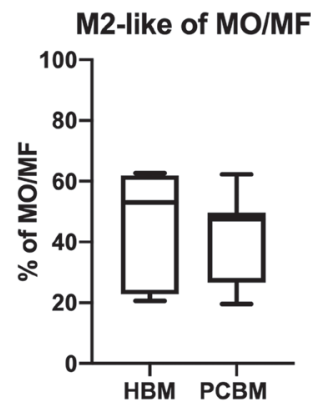

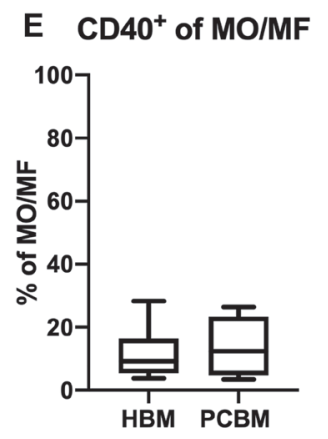

$J$

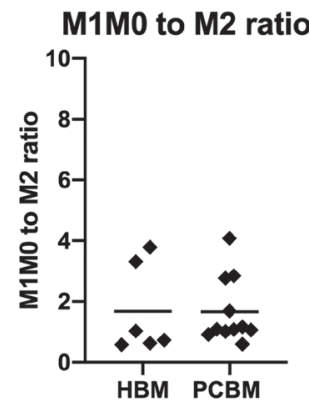

Figure 6: Monocyte/macrophage polarization in BM aspirates. Data represents frequency of cells expressing (A) CD14 ${ }^{\text {bright }}$, (B) HLA-II ${ }^{+}$, (C) CD163 ${ }^{\text {bright }}$, (D) CD200R, (E) CD40, (F) B7H3, (G) PDL1 protein within the total monocyte/macrophage subset. Box plots in $(\mathbf{H}-\mathbf{J})$ represent M1/M2 polarization in BM aspirates. Data shows frequency of enriched M1M0-like (H) or M2-like (I) monocyte/ macrophages within the total MO/MF subset. All box plots with whiskers represent data distribution with median line, Min to Max. The dot plot (J) represents the M1M0 to M2 ratio within each sample with Mean. $\operatorname{HBM} n=6, \operatorname{PCBM} n=11 .{ }^{*} p<0.05,{ }^{* *} p<0.01$. 
computational flow analysis of men undergoing routine tests for PC including asymptomatic PC patients with very low PSA $(<20 \mathrm{ng} / \mathrm{ml})$ identified peripheral blood NKT cells as strong biomarker of carcinoma presence in biopsy cores. This study suggested that computational analysis of the peripheral immune profile improved diagnostic accuracy when used in addition to PSA monitoring [33]. Similarly, we found a correlation between PSA levels and BM NKT yields that further supports the hypothesis that peripheral NKT enrichment reflects early PC tumorigenesis. The prognostic value of this biomarker should be further explored in a larger patient cohort with expanded clinical correlates including time to biochemical recurrence.

Myeloid cells, including granulocytes and MDSCs, are also recognized to have major roles in anti-tumor immunity. Although there were no overt differences in the frequency of MDSCs or granulocytes in this study, we did find that the frequency of CD $11 b^{+}$enriched dendritic cells (DCs) was significantly reduced in patients with localized prostate cancer. DCs are the prime antigen presenting cells involved in $\mathrm{T}$ cell activation and tumor immune surveillance [34]. While they can initiate dramatic immune-mediated tumor rejection, the immunogenic activity of DCs is directly linked to their abundance within the tumor microenvironment. Preclinical data in a murine model of BM metastasis demonstrated PC-mediated inhibition of DC generation [35]. Thus, the reduction of
DC number in patients with localized PC suggests that the DC population at this early stage of disease may be less effective at initiating an adaptive immune response against tumor cells within the BM.

In the monocyte/macrophage populations, we identified an increase in expression of the immune checkpoint molecule, $\mathrm{B} 7 \mathrm{H} 3 . \mathrm{B} 7 \mathrm{H} 3$ is a regulator of $\mathrm{T}$ cell function [36], and is related to both AR-signaling and the immune reactome. $\mathrm{B} 7 \mathrm{H} 3$ showed correlation with Gleason score, cancer stage and poor oncologic outcomes in a large cohort of prostatectomy specimens [37]. The role of the $\mathrm{B} 7 \mathrm{H} 3$ immune checkpoint in regulation of the pre-metastatic PC immune microenvironment should be further investigated. A Phase II clinical trial is currently evaluating the anti-tumor effect and immunogenicity of anti-B7H3 (Enoblituzumab) neoadjuvant therapy given to patients prior to radical prostatectomy (NCT02923180).

M2-like tumor-associated macrophages have been reported in both primary prostate carcinomas and in castrate-resistant PC [38] and may have potential as a biomarker for biochemical recurrence in PC [39]. In current study, we found no evidence of a macrophage polarization shift between healthy donors and PC patients. However, our scope has been limited to a binary phenotypic characterization in a relatively small cohort and functional assessment of the BM MOMF should be further explored in PC BM.

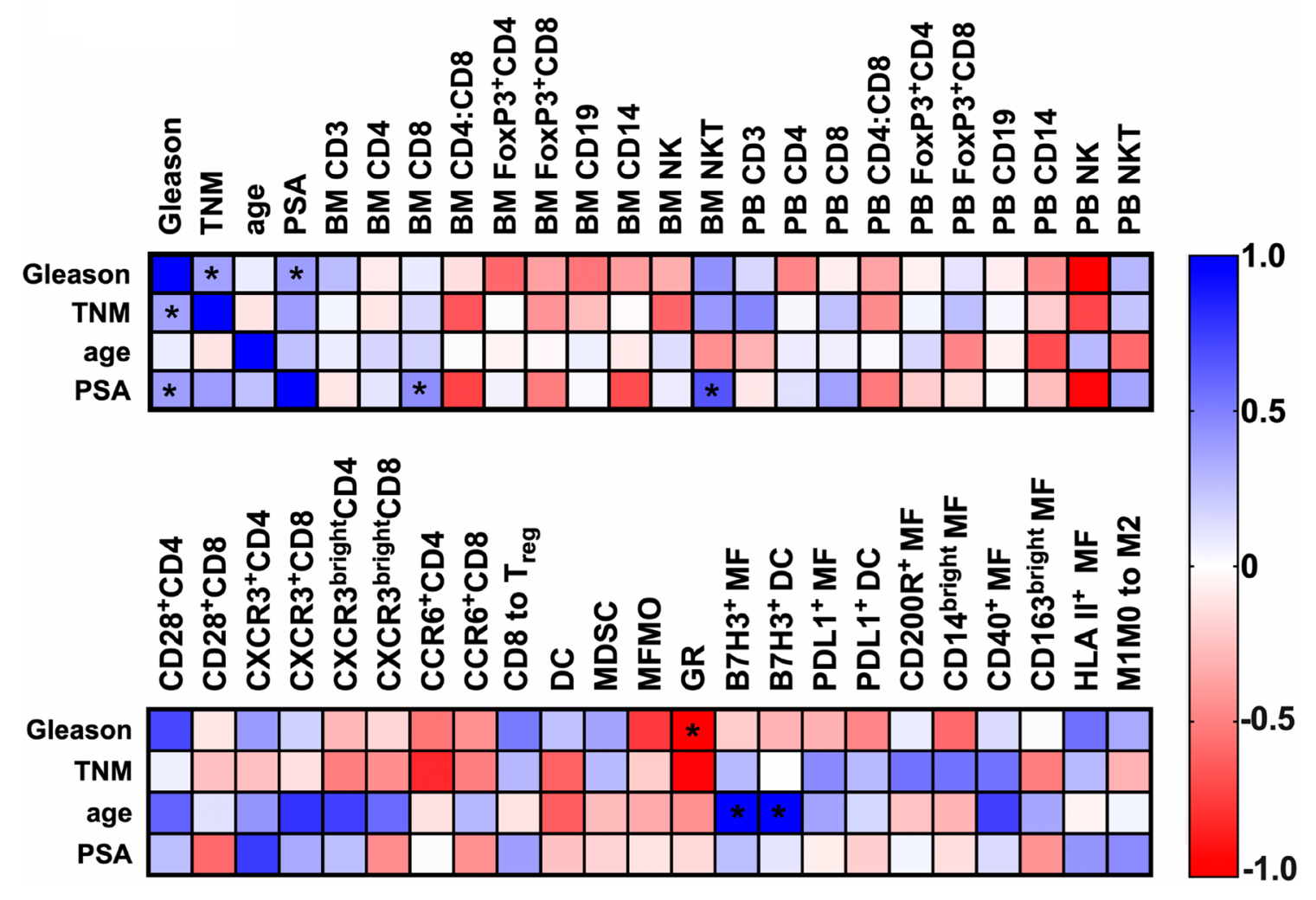

Figure 7: Spearman's correlation analysis of patient characteristics and immunologic features. Heatmaps represent rho values in Spearman correlation matrices of patient data and immunologic features of bone marrow aspirates and of peripheral blood in PC patients. (top) $\mathrm{BM} n=11-27, \mathrm{~PB} n=11-22$; (bottom) $n=11-14 .{ }^{*} p<0.05,{ }^{* *} p<0.01$. 
Our observations suggest that an active interplay between myeloid and lymphoid compartments is present in $\mathrm{BM}$ in the absence of detectable metastasis, and raises the hypothesis that an immunosuppressive BM environment predisposes patients to recurrent disease. Therefore, immune aberrations could potentially be detected prior to disseminated tumor cells (DTCs) and radiographic evidence of bone metastases.

BM samples of prostatectomy patients have been previously assessed with various rare-event detection methods in an attempt to aid patient stratification. A recent study by Chalfin et al. which included 12 out of $27 \mathrm{BM}$ from the current samples concluded that the detection of DTCs in BM was a rare occurrence [40]. Herein, we show that aberrations in $\mathrm{BM}$ immune homeostasis are more common events than DTCs, suggesting that detection of immune alterations could potentially be a more useful stratification marker to predict patients at higher risk for recurrence. While the sample size and duration of follow-up in this study were not sufficient to make definitive conclusions, the array of lymphoid and myeloid alterations in patients with organconfined PC are consistent with an increased risk for BM metastases. Future studies evaluating the multi-cellular BM microenvironment in both aspirates and in biopsies and clinical follow-up to identify patients with early biochemical recurrence are critically needed to understand whether immune suppressive events precede early BM invasion and if immune alterations in patients with PC could be therapeutically targeted to prevent bone metastasis.

In this paper, we describe a comprehensive interrogation of the immune compartment in BM from patients with clinically localized PC. Our findings demonstrate that immunosuppressive alterations of the lymphoid and myeloid compartments within the BM can occur early in PC pathogenesis. In the process of tumor cell metastasis, such alterations could promote the outgrowth of disseminating prostate cancer cells within the BM. As such, the presence of these alterations may hold important prognostic significance as well as predict which patients might benefit from more aggressive therapy. Our report provides the first in-depth analysis of the BM immune phenotype in primary, localized PC. These findings highlight the importance of the unique niche present in bone and bone marrow, and provide rationale for further research of the osseous immune microenvironment in patients with prostate cancer.

\section{MATERIALS AND METHODS}

\section{Patients}

The study was approved by the institutional review board at University of Wisconsin and Johns Hopkins University. The study enrolled a total of 29 prostate cancer patients providing written consent to collect BM aspirates and peripheral blood while undergoing radical prostatectomy for presumed localized disease. From the 29 donors, we have received and analyzed a total of 27 BM aspirates and 24 PB samples, of which 22 samples were completely matched. Patient characteristics including Gleason score, TNM stage, age, PSA, pertinent laboratory values, and clinical outcomes are summarized in Table 1. Healthy BM aspirates were obtained from 5 male BM donors at Johns Hopkins University, and from left over BM filters of 5 healthy individuals [41] providing BM for donor transplantation at the University of Wisconsin BM Transplant program IRB\# 2016-0298.

\section{BM and peripheral blood processing}

Blood was collected into $\mathrm{K}_{2}$ EDTA Vacutainer tubes (BD Biosciences, USA). BM aspirates were collected in a heparinized tube and inverted immediately followed by an hour digestion with Heparin (100 IU/ $\mathrm{ml})$ and DNase I (100 IU/ml). Mononuclear cells were isolated from pre-processed BM samples using density gradient centrifugation overlaid on LSM media (Corning, USA) following manufacturer's protocol. PBMCs from peripheral blood (PB) were isolated on Ficoll-Paque (GE, USA) gradient.

\section{Flow cytometry}

Using multicolor flow cytometry, the immune compartment in matched blood and BM samples were examined. $\sim 2$ million PBMCs were stained with a comprehensive panel for immune staining. The initial cohort of 15 patient samples were analyzed with a basic panel utilizing Ghost Dye ${ }^{\mathrm{TM}}$ Violet 510 (Tonbo Biosciences, San Diego, CA, USA), human Fc blocker (BD Biosciences, San Jose, CA, USA) and antibodies including CD45-PE, CD19FITC, CD4 Brilliant Violet ${ }^{\mathrm{TM}}$ 421, CD8 APC-Cy7, FoxP3APC and CD14 Brilliant Violet ${ }^{\mathrm{TM}}$ 786. To gain higher granularity data on activation and functional polarization the assays were expanded into two panels including CD45, CD19, CD14, CD3, CD11b, CD56, CD163, CD200R, HLA II, B7H3, PDL1, CD40 in Panel I and CD45, CD4, CD8, FoxP3, CD82, CXCR3, CXCR5, CCR4, CCR6, CD103 in Panel II, with further details summarized in Supplementary Table 1. Cells were stained with human Fc blocker, Ghost Dye $^{\mathrm{TM}}$ Violet 510 stain and fluorescently conjugated antibodies for immune labeling of surface markers. Surface staining was followed by a washing step and fixation with 2\% PFA (Cytofix, BD Biosciences, San Jose, CA, USA) in Panel I or fixation \& permeabilization for intracellular staining with the FoxP3 Staining kit following the manufacturer's protocol (eBioscience portfolio by Thermo Fisher Scientific, Waltham, MA, USA) in Panel II. Samples were acquired following pre-acquisition instrument standardization with Mid-Range Ultra Rainbow Fluorescent Particles (Spherotech, Lake Forest, IL, USA) on a BD LSR II instrument at the UWCCC Flow Cytometry Laboratory. 
Gating controls included Internal Negative Controls (INCs) and Fluorescent Minus One (FMO) controls [42]. Due to limited sample size, the FMOs were established on an independent cohort of donor PBMC with matched assay and instrument settings to confirm no spectral spillover into positive gating areas. Representative plots for gating strategies are included in Figures 1A, 5A and Supplementary Figure 2. Monocytes $\left(\mathrm{CD} 45^{\mathrm{in}} \mathrm{SSC}_{\text {int }}\right)$ served as INC to validate gating thresholds for CD28, CXCR5, CXCR3 and CD103 expression [43, 44]. The CD45-SSC subset served as INC for CCR4 and FoxP3 expression. CCR6 expression was cross-examined on $\mathrm{CD}^{+} \mathrm{CD} 8^{+}$ double positive lymphocytes and the CXCR $3^{\text {bright }}$ subset to confirm gating thresholds [45, 46]. Lymphocytes $\left(\mathrm{CD} 45^{\text {bright }} \mathrm{SSC}_{\text {low }}\right.$ ) served to confirm baseline thresholds for myeloid markers (Supplementary Figure 2B). B7H3 and PDL1 are primarily expressed in myeloid leukocytes while the majority of lymphocytes do not express these proteins and align with FMO baselines [47-49]. The $\mathrm{CD}^{+}$fraction and the majority of lymphocytes are both negative for CD40 and $\mathrm{CD} 19^{+}$cells serve as an internal positive control [50]. CD19 ${ }^{+} \mathrm{B}$ cells served to set baseline threshold for CD200R expression [24]. CD163 is expressed by macrophages and is upregulated on M2 macrophages [22]. For the M2 analysis, we gated on the $\mathrm{CD} 163^{\text {bright }}$ subset [51]. The CD163 bright, CD14 ${ }^{\text {bright }}$ and HLA II ${ }^{\text {bright }}$ subsets were gated on the top, brightly expressing, spectrally distinct subsets within those positive fractions.

The flow cytometry data was analyzed by FlowJo Ver. 9.9.6 (BD Biosciences, San Jose, CA, USA).

\section{Statistical analysis}

Statistical comparison between groups was made with Welch's $t$-test in Prism 8 Version 8.4.2 (GraphPad Software, San Diego, CA, USA). Correlation analysis of patient data and immune phenotype were done with Spearman's $r$ in Prism 8.

\section{Abbreviations}

BM: bone marrow; GR: granulocyte; DC: dendritic cell; FSC: forward scatter; MDSC: myeloid-derived suppressor cell; MO/MF: monocyte/macrophage; NK: natural killer cell; NKT: natural killer T cell; PB: peripheral blood; PC: prostate cancer; PSA: prostate-specific antigen; SSC: side scatter; TNM: tumor node metastasis staging.

\section{Author contributions}

EH and NS performed experiments; KJP, PH, MDK, JML, NS organized patient study and sample collection; EH, DK, NS, KJP and JML contributed to data analysis; EH, DK, NS, KJP, JML wrote the manuscript; JML supervised study; all authors read and discussed manuscript.

\section{ACKNOWLEDGMENTS}

We are grateful for the support of patients who donated samples for this study. We thankfully acknowledge the technical assistance of Dr Anupama Singh and Serena Wolfe in processing samples and Dr Jamie Sperger for her support in writing of the manuscript.

\section{CONFLICTS OF INTEREST}

JML holds equity in Salus Discovery LLC.

\section{FUNDING}

This work was supported by the 16CHAL04 Movember Foundation and Prostate Cancer Foundation Challenge Award, awarded to JML. This work was supported by the Assistant Secretary of Defense for Health Affairs through the Prostate Cancer Research Program, Award No. W81XWH-16-1-0511 to JML and W81XWH-18-1-0273 to DK. NS was supported as a research fellow through the Advanced Fellowship in Women's Health/Department of Geriatrics at the William S. Middleton Veterans Affairs Hospital, Madison, WI, and is currently supported by a UW NRSA T32 post-doctoral award (5T32HL007899-23). Opinions, interpretations, conclusions and recommendations are those of the author and are not necessarily endorsed by the Department of Defense. The U.S. Army Medical Research Acquisition Activity, 820 Chandler Street, Fort Detrick MD 217025014 is the awarding and administering acquisition office. The views expressed in this article are those of the authors and do not necessarily reflect the position or policy of the Department of Veterans Affairs or the United States government. Additionally, we acknowledge shared resources grant support for the University of Wisconsin Carbone Cancer Center Support Grant P30 CA014520 by the NIH for both the UWCCC Flow Cytometry Lab and Biostatistics Shared Resource at UWCCC.

\section{REFERENCES}

1. Eggermont AM, Chiarion-Sileni V, Grob JJ, Dummer R, Wolchok JD, Schmidt H, Hamid O, Robert C, Ascierto PA, Richards JM, Lebbe C, Ferraresi V, Smylie M, et al. Prolonged Survival in Stage III Melanoma with Ipilimumab Adjuvant Therapy. N Engl J Med. 2016; 375:1845-1855. https://doi.org/10.1056/NEJMoa1611299. [PubMed]

2. Ferris RL, Blumenschein G Jr, Fayette J, Guigay J, Colevas AD, Licitra L, Harrington K, Kasper S, Vokes EE, Even C, Worden F, Saba NF, Iglesias Docampo LC, et al. Nivolumab for Recurrent Squamous-Cell Carcinoma of the Head and Neck. N Engl J Med. 2016; 375:1856-1867. https://doi. org/10.1056/NEJMoa1602252. [PubMed] 
3. Hodi FS, O’Day SJ, McDermott DF, Weber RW, Sosman JA, Haanen JB, Gonzalez R, Robert C, Schadendorf D, Hassel JC, Akerley W, van den Eertwegh AJ, Lutzky J, et al. Improved survival with ipilimumab in patients with metastatic melanoma. N Engl J Med. 2010; 363:711-723. https://doi.org/10.1056/NEJMoa1003466. [PubMed]

4. Paz-Ares L, Luft A, Vicente D, Tafreshi A, Gumus M, Mazieres J, Hermes B, Cay Senler F, Csoszi T, Fulop A, Rodriguez-Cid J, Wilson J, Sugawara S, et al. Pembrolizumab plus Chemotherapy for Squamous NonSmall-Cell Lung Cancer. N Engl J Med. 2018; 379:2040 2051. https://doi.org/10.1056/NEJMoa1810865. [PubMed]

5. Schmid P, Adams S, Rugo HS, Schneeweiss A, Barrios $\mathrm{CH}$, Iwata H, Dieras V, Hegg R. Atezolizumab and NabPaclitaxel in Advanced Triple-Negative Breast Cancer. N Engl J Med. 2018; 379:2108-2121. https://doi.org/10.1056/ NEJMoa1809615. [PubMed]

6. Antonarakis ES, Piulats JM, Gross-Goupil M, Goh J, Ojamaa K, Hoimes CJ, Vaishampayan U, Berger R, Sezer A, Alanko T, de Wit R, Li C, Omlin A, et al. Pembrolizumab for Treatment-Refractory Metastatic Castration-Resistant Prostate Cancer: Multicohort, Open-Label Phase II KEYNOTE-199 Study. J Clin Oncol. 2020; 38:395-405. https://doi.org/10.1200/JCO.19.01638. [PubMed]

7. Beer TM, Kwon ED, Drake CG, Fizazi K, Logothetis C, Gravis G, Ganju V, Polikoff J, Saad F, Humanski P, Piulats JM, Gonzalez Mella P, Ng SS, et al. Randomized, DoubleBlind, Phase III Trial of Ipilimumab Versus Placebo in Asymptomatic or Minimally Symptomatic Patients With Metastatic Chemotherapy-Naive Castration-Resistant Prostate Cancer. J Clin Oncol. 2017; 35:40-47. https://doi. org/10.1200/JCO.2016.69.1584. [PubMed]

8. Calcinotto A, Spataro C, Zagato E, Di Mitri D, Gil V, Crespo M, De Bernardis G, Losa M, Mirenda M, Pasquini E, Rinaldi A, Sumanasuriya S, Lambros MB, et al. IL-23 secreted by myeloid cells drives castration-resistant prostate cancer. Nature. 2018; 559:363-369. https://doi.org/10.1038/ s41586-018-0266-0. [PubMed]

9. Comiskey MC, Dallos MC, Drake CG. Immunotherapy in Prostate Cancer: Teaching an Old Dog New Tricks. Curr Oncol Rep. 2018; 20:75. https://doi.org/10.1007/s11912018-0712-z. [PubMed]

10. Hansen AR, Massard C, Ott PA, Haas NB, Lopez JS, Ejadi S, Wallmark JM, Keam B, Delord JP, Aggarwal R, Gould M, Yang P, Keefe SM, et al. Pembrolizumab for advanced prostate adenocarcinoma: findings of the KEYNOTE-028 study. Ann Oncol. 2018; 29:1807-1813. https://doi. org/10.1093/annonc/mdy232. [PubMed]

11. Kwon ED, Drake CG, Scher HI, Fizazi K, Bossi A, van den Eertwegh AJ, Krainer M, Houede N, Santos R, Mahammedi H, Ng S, Maio M, Franke FA, et al. Ipilimumab versus placebo after radiotherapy in patients with metastatic castration-resistant prostate cancer that had progressed after docetaxel chemotherapy (CA184-043): a multicentre, randomised, double-blind, phase 3 trial. Lancet
Oncol. 2014; 15:700-712. https://doi.org/10.1016/S14702045(14)70189-5. [PubMed]

12. Childs R, Chernoff A, Contentin N, Bahceci E, Schrump D, Leitman S, Read EJ, Tisdale J, Dunbar C, Linehan WM, Young NS, Barrett AJ. Regression of metastatic renal-cell carcinoma after nonmyeloablative allogeneic peripheral-blood stem-cell transplantation. $\mathrm{N}$ Engl J Med. 2000; 343:750-758. https://doi.org/10.1056/ NEJM200009143431101. [PubMed]

13. Feuerer M, Beckhove P, Bai L, Solomayer EF, Bastert G, Diel IJ, Pedain C, Oberniedermayr M, Schirrmacher V, Umansky V. Therapy of human tumors in NOD/SCID mice with patient-derived reactivated memory $\mathrm{T}$ cells from bone marrow. Nat Med. 2001; 7:452-458. https://doi. org/10.1038/86523. [PubMed]

14. Schmitz-Winnenthal FH, Volk C. Z'Graggen K, Galindo L, Nummer D, Ziouta Y, Bucur M, Weitz J, Schirrmacher V, Buchler MW, Beckhove P. High frequencies of functional tumor-reactive $\mathrm{T}$ cells in bone marrow and blood of pancreatic cancer patients. Cancer Res. 2005; 65:1007910087. https://doi.org/10.1158/0008-5472.CAN-05-1098. [PubMed]

15. Shah RB, Mehra R, Chinnaiyan AM, Shen R, Ghosh D, Zhou M, Macvicar GR, Varambally S, Harwood J, Bismar TA, Kim R, Rubin MA, Pienta KJ. Androgen-independent prostate cancer is a heterogeneous group of diseases: lessons from a rapid autopsy program. Cancer Res. 2004; 64:9209-9216. https://doi.org/10.1158/0008-5472.CAN-042442. [PubMed]

16. Bofill M, Janossy G, Lee CA, MacDonald-Burns D, Phillips AN, Sabin C, Timms A, Johnson MA, Kernoff PB. Laboratory control values for CD4 and CD8 T lymphocytes. Implications for HIV-1 diagnosis. Clin Exp Immunol. 1992; 88:243252. https://doi.org/10.1111/j.1365-2249.1992.tb03068.x. [PubMed]

17. Clark P, Normansell DE, Innes DJ, Hess CE. Lymphocyte subsets in normal bone marrow. Blood. 1986; 67:16001606. https://doi.org/10.1182/blood.V67.6.1600.1600. [PubMed]

18. Di Rosa F, Pabst R. The bone marrow: a nest for migratory memory T cells. Trends Immunol. 2005; 26:360-366. https://doi.org/10.1016/j.it.2005.04.011. [PubMed]

19. Roederer M, Quaye L, Mangino M, Beddall MH, Mahnke Y, Chattopadhyay P, Tosi I, Napolitano L, Terranova Barberio M, Menni C, Villanova F, Di Meglio P, Spector TD, et al. The genetic architecture of the human immune system: a bioresource for autoimmunity and disease pathogenesis. Cell. 2015; 161:387-403. https://doi.org/10.1016/j. cell.2015.02.046. [PubMed]

20. Groom JR, Luster AD. CXCR3 in T cell function. Exp Cell Res. 2011; 317:620-631. https://doi.org/10.1016/j. yexcr.2010.12.017. [PubMed]

21. Gustafson MP, Lin Y, Maas ML, Van Keulen VP, Johnston PB, Peikert T, Gastineau DA, Dietz AB. A method for identification and analysis of non-overlapping 
myeloid immunophenotypes in humans. PLoS One. 2015; 10:e0121546. https://doi.org/10.1371/journal. pone.0121546. [ [PubMed]

22. Etzerodt A, Moestrup SK. CD163 and inflammation: biological, diagnostic, and therapeutic aspects. Antioxid Redox Signal. 2013; 18:2352-2363. https://doi.org/10.1089/ ars.2012.4834. [PubMed]

23. Jenmalm MC, Cherwinski H, Bowman EP, Phillips JH, Sedgwick JD. Regulation of myeloid cell function through the CD200 receptor. J Immunol. 2006; 176:191-199. https://doi.org/10.4049/jimmunol.176.1.191. [PubMed]

24. Wright GJ, Cherwinski H, Foster-Cuevas M, Brooke G, Puklavec MJ, Bigler M, Song Y, Jenmalm M, Gorman D, McClanahan T, Liu MR, Brown MH, Sedgwick JD, et al. Characterization of the CD200 receptor family in mice and humans and their interactions with CD200. J Immunol. 2003; 171:3034-3046. https://doi.org/10.4049/ jimmunol.171.6.3034. [PubMed]

25. Dittmer JE, Oh SK, Corwin L, Bennett M. Suppression of tumor cell growth in vitro by a bone marrow factor. Cancer Res. 1984; 44:900-903. [PubMed]

26. Larmonier N, Ghiringhelli F, Larmonier CB, Moutet M, Fromentin A, Baulot E, Solary E, Bonnotte B, Martin F. Freshly isolated bone marrow cells induce death of various carcinoma cell lines. Int J Cancer. 2003; 107:747-756. https://doi.org/10.1002/ijc.11463. [PubMed]

27. Diederichsen AC, Hjelmborg J, Christensen PB, Zeuthen J, Fenger C. Prognostic value of the CD4+/CD8+ ratio of tumour infiltrating lymphocytes in colorectal cancer and HLA-DR expression on tumour cells. Cancer Immunol Immunother. 2003; 52:423-428. https://doi.org/10.1007/ s00262-003-0388-5. [PubMed]

28. Markowska J, Lacki JK, Jaroszewski J, Wiktorowicz K. The usefulness of CD4/CD8 ratio evaluation in monitoring of ovarian cancer patients. Eur J Gynaecol Oncol. 1995; 16:54-58. [PubMed]

29. Wang K, Shen T, Siegal GP, Wei S. The CD4/CD8 ratio of tumor-infiltrating lymphocytes at the tumor-host interface has prognostic value in triple-negative breast cancer. Hum Pathol. 2017; 69:110-117. https://doi.org/10.1016/j. humpath.2017.09.012. [PubMed]

30. Wahlin BE, Sander B, Christensson B, Ostenstad B, Holte H, Brown PD, Sundstrom C, Kimby E. Entourage: the immune microenvironment following follicular lymphoma. Blood Cancer J. 2012; 2:e52. https://doi.org/10.1038/ bcj.2011.53. [PubMed]

31. Cerqueira MA, Ferrari KL, de Mattos AC, Monti CR, Reis LO. T cells CD4+/CD8+ local immune modulation by prostate cancer hemi-cryoablation. World J Urol. 2020; 38:673-680. https://doi.org/10.1007/s00345-019-02861-0. [PubMed]

32. Pasero C, Gravis G, Granjeaud S, Guerin M, ThomassinPiana J, Rocchi P, Salem N, Walz J, Moretta A, Olive D. Highly effective NK cells are associated with good prognosis in patients with metastatic prostate cancer. Oncotarget. 2015; 6:14360-14373. https://doi.org/10.18632/ oncotarget.3965. [PubMed]

33. Cosma G, McArdle SE, Reeder S, Foulds GA, Hood S, Khan M, Pockley AG. Identifying the Presence of Prostate Cancer in Individuals with PSA Levels $<20 \mathrm{ng}$ ml(-1) Using Computational Data Extraction Analysis of High Dimensional Peripheral Blood Flow Cytometric Phenotyping Data. Front Immunol. 2017; 8:1771. https:// doi.org/10.3389/fimmu.2017.01771. [PubMed]

34. Nussenzweig MC, Steinman RM, Gutchinov B, Cohn ZA. Dendritic cells are accessory cells for the development of anti-trinitrophenyl cytotoxic T lymphocytes. J Exp Med. 1980; 152:1070-1084. https://doi.org/10.1084/ jem.152.4.1070. [ubMed]

35. Tourkova IL, Yamabe K, Chatta G, Shurin GV, Shurin MR. NK cells mediate Flt3 ligand-induced protection of dendritic cell precursors in vivo from the inhibition by prostate carcinoma in the murine bone marrow metastasis model. J Immunother. 2003; 26:468-472. https://doi. org/10.1097/00002371-200311000-00002. [PubMed]

36. Chen C, Shen Y, Qu QX, Chen XQ, Zhang XG, Huang JA. Induced expression of B7-H3 on the lung cancer cells and macrophages suppresses T-cell mediating anti-tumor immune response. Exp Cell Res. 2013; 319:96-102. https:// doi.org/10.1016/j.yexcr.2012.09.006. [PubMed]

37. Benzon B, Zhao SG, Haffner MC, Takhar M, Erho N, Yousefi K, Hurley P, Bishop JL, Tosoian J, Ghabili K, Alshalalfa M, Glavaris S, Simons BW, et al. Correlation of B7-H3 with androgen receptor, immune pathways and poor outcome in prostate cancer: an expression-based analysis. Prostate Cancer Prostatic Dis. 2017; 20:28-35. https://doi. org/10.1038/pcan.2016.49. [PubMed]

38. Zarif JC, Baena-Del Valle JA, Hicks JL, Heaphy CM, Vidal I, Luo J, Lotan TL, Hooper JE, Isaacs WB, Pienta KJ, De Marzo AM. Mannose Receptor-positive Macrophage Infiltration Correlates with Prostate Cancer Onset and Metastatic Castration-resistant Disease. Eur Urol Oncol. 2019; 2:429-436. https://doi.org/10.1016/j. euo.2018.09.014. [PubMed]

39. Zhang Q, Xia J, Wang Y, Zhang J, Ji C, Cong R, Wang Y, Song N. Tumor infiltrating M2 macrophages could predict biochemical recurrence of localized prostate cancer after radical prostatectomy. Exp Cell Res. 2019; 384:111588. https://doi.org/10.1016/j.yexcr.2019.111588. [PubMed]

40. Chalfin HJ, Glavaris SA, Malihi PD, Sperger JM, Gorin MA, Lu C, Goodwin CR, Chen Y, Caruso EA, Dumpit R, Kuhn P, Lang JM, Nelson PS, et al. Prostate Cancer Disseminated Tumor Cells are Rarely Detected in the Bone Marrow of Patients with Localized Disease Undergoing Radical Prostatectomy across Multiple Rare Cell Detection Platforms. J Urol. 2018; 199:1494-1501. https://doi. org/10.1016/i.juro.2018.01.033. [PubMed]

41. Bouchlaka MN, Moffitt AB, Kim J, Kink JA, Bloom DD, Love C, Dave S, Hematti P, Capitini CM. Human 
Mesenchymal Stem Cell-Educated Macrophages Are a Distinct High IL-6-Producing Subset that Confer Protection in Graft-versus-Host-Disease and Radiation Injury Models. Biol Blood Marrow Transplant. 2017; 23:897-905. https:// doi.org/10.1016/j.bbmt.2017.02.018. [PubMed]

42. Hulspas R, O'Gorman MR, Wood BL, Gratama JW, Sutherland DR. Considerations for the control of background fluorescence in clinical flow cytometry. Cytometry B Clin Cytom. 2009; 76:355-364. https://doi. org/10.1002/cyto.b.20485. [PubMed]

43. Sandblad KG, Jones P, Kostalla MJ, Linton L, Glise H, Winqvist O. Chemokine receptor expression on monocytes from healthy individuals. Clin Immunol. 2015; 161:348 353. https://doi.org/10.1016/j.clim.2015.09.012. [PubMed]

44. Geissmann F, Jung S, Littman DR. Blood monocytes consist of two principal subsets with distinct migratory properties. Immunity. 2003; 19:71-82. https://doi.org/10.1016/S10747613(03)00174-2. [PubMed]

45. Silveira-Mattos PS, Narendran G, Akrami K, Fukutani KF, Anbalagan S, Nayak K, Subramanyam S, Subramani R, Vinhaes CL, Souza DO, Antonelli LR, Satagopan K, Porter $\mathrm{BO}$, et al. Differential expression of CXCR3 and CCR6 on CD4(+) T-lymphocytes with distinct memory phenotypes characterizes tuberculosis-associated immune reconstitution inflammatory syndrome. Sci Rep. 2019; 9:1502. https://doi. org/10.1038/s41598-018-37846-3. [PubMed]

46. Friess GG, Brown TD, Wrenn RC. Improvement in cardiac ectopy during gamma interferon infusion: a case report. Cancer Treat Rep. 1986; 70:1463-1464. [ubMed]
47. Zhao Y, Harrison DL, Song Y, Ji J, Huang J, Hui E. AntigenPresenting Cell-Intrinsic PD-1 Neutralizes PD-L1 in cis to Attenuate PD-1 Signaling in T Cells. Cell Rep. 2018; 24: 379-90.e6. https://doi.org/10.1016/j.celrep.2018.06.054. [PubMed]

48. Arrieta O, Montes-Servin E, Hernandez-Martinez JM, Cardona AF, Casas-Ruiz E, Crispin JC, Motola D, FloresEstrada D, Barrera L. Expression of PD-1/PD-L1 and PDL2 in peripheral T-cells from non-small cell lung cancer patients. Oncotarget. 2017; 8:101994-102005. https://doi. org/10.18632/oncotarget.22025. [PubMed]

49. Chapoval AI, Ni J, Lau JS, Wilcox RA, Flies DB, Liu D, Dong H, Sica GL, Zhu G, Tamada K, Chen L. B7-H3: a costimulatory molecule for $\mathrm{T}$ cell activation and IFNgamma production. Nat Immunol. 2001; 2:269-274. https:// doi.org/10.1038/85339. [PubMed]

50. van Kooten C, Banchereau J. CD40-CD40 ligand. J Leukoc Biol. 2000; 67:2-17. https://doi.org/10.1002/jlb.67.1.2. [PubMed]

51. Groselj-Grenc M, Ihan A, Derganc M. Neutrophil and monocyte CD64 and CD163 expression in critically ill neonates and children with sepsis: comparison of fluorescence intensities and calculated indexes. Mediators Inflamm. 2008; 2008:202646. https://doi. org/10.1155/2008/202646. [PubMed] 